\title{
Antioxidant Properties of Some Filamentous Green Algae (Chaetomorpha Genus)
}

\author{
Massoumeh Farasat ${ }^{1 *}$, Ramazan-Ali Khavari-Nejad ${ }^{1}$, Seyed Mohammad Bagher Nabavi ${ }^{2}$ \\ and Foroogh Namjooyan ${ }^{3}$ \\ ${ }^{1}$ Department of Biology; Science and Research Branch; Islamic Azad University; Tehran - Iran. ${ }^{2}$ Faculty of Marine \\ Science; University of Marine Sciences and Technology; Khorramshahr - Iran. ${ }^{3}$ Marine Pharmaceutical Research \\ Center; Pharmacognosy Department; School of Pharmacy; Ahvaz Jundishapur University of Medical Sciences; \\ Ahvaz - Iran
}

\begin{abstract}
The antioxidant activity and the contents of total phenolics and flavonoids were quantified in the methanolic extracts of four Chaetomorpha species including C. aerea, C. crassa, C. linum and C. brachygona. Eight samples of Chaetomorpha plants were collected from five locations along the northern coasts of the Persian Gulf in south of Iran from December 2010 until October 2011. Methanolic extracts of the seaweeds were assessed for their antioxidant activity using DPPH radical scavenging assay. C. linum showed highest antioxidant potential with a relatively low $I_{50}\left(1.484 \pm 0.168 \mathrm{mg} \mathrm{mL}^{-1}\right)$, the highest flavonoid content $\left(18.177 \pm 2.238 \mathrm{mg} \mathrm{RE}^{-1}\right)$ and a

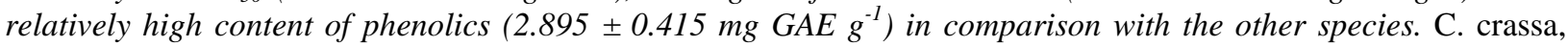
which was collected from two different areas, showed lowest antioxidant activity and lowest phenolics and flavonoid contents than other species. Results revealed that $I C_{50}$, total phenolics and flavonoid content were influenced by the time of collection and location. Also there were positive correlations between the phenolic and flavonoid contents with DPPH radical scavenging activity $(p<0.01)$. The results suggested that some of these filamentous green seaweeds possessed antioxidant potential, which could be considered for future applications in medicine, food or cosmetic industries.
\end{abstract}

Key words: Antioxidant, Phenolics, Flavonoid, DPPH, Green algae, Chaetomorpha

\section{INTRODUCTION}

Oxidative stress plays an important role in the pathogenesis of various diseases such as atherosclerosis, alcoholic liver cirrhosis, cancer, etc. Oxidative stress is initiated by free radicals, especially reactive oxygen species (ROS). Most living species have efficient defense systems to prevent themselves against the oxidative stress induced by the ROS (Hazra et al. 2010). In the past decade, antioxidants have shown their role in the prevention of various diseases, in which free radicals are implicated (Lee et al. 2007).The most widely used synthetic antioxidants in food such as BHT (butylated hydroxytoluene) and BHA (butylated hydroxyanisole) have been suspected to cause negative health effects (Kulisic et al. 2004). Concerns about the safety of the synthetic antioxidants have led to increased interest on natural antioxidants, which are commonly found in the plants and seaweeds (Duan et al. 2006).

Seaweeds are known to contain a wide variety of bioactive compounds, many of which have commercial applications in the pharmaceutical, medical, cosmetic, food industries and agriculture (Kelman et al. 2012). As a result, many marine

\footnotetext{
*Author for correspondence: m.farasat@ srbiau.ac.ir
} 
algae in the last decades have attracted the attention to the search for natural bioactive compounds to develop new drugs and health foods. Compounds with antioxidant, antiviral, antifungal and antimicrobial activities have been found in brown, red and green algae (Cox et al. 2010).

The antioxidant activity of several seaweeds has been reported (Boonchum et al. 2011). Chaetomorpha is a common and widespread green seaweed genus, which is characterized by unbranched filaments (Leliaraert et al. 2011). Chaetomorpha, also known as Spaghetti algae, contains vitamins C and A (Novaczek 2001). Some species are edible such as $C$. crassa, $C$. linum and C. brachygona. C. crassa is consumed as salad, or dessert in far eastern countries due to its character of gelatinization (Apaydin-Yagci and Turna 2002). Apparently, there is no study done so far on the antioxidant activities of filamentous green seaweeds from south of Iran. Thus, the current study aimed to investigate the antioxidant capacity, total phenolics and flavonoids of Chaetomorpha species from the northern coasts of the Persian Gulf for possible applications in medicine, dietary supplements, cosmetics, or food industries.

\section{MATERIALS AND METHODS}

\section{Chemicals}

Ascorbic acid, Folin-Ciocalteu reagent, gallic acid and methanol were purchased from Merck Company (Darmstadt, Germany). DPPH and Rutin were purchased from Sigma Chemical Co (St. Louis, MO, USA). All the chemicals and reagents used were of analytical grade.

\section{Collection and Preparing of Algal Extracts}

The seaweeds were collected at low tide time along the northern coasts of the Persian Gulf in south of Iran from December 2010 until October 2011. After the harvest, they were washed with fresh water to remove the sands, salts and epiphytes, and then were air-dried at room temperature with good controlled air conditioning. Voucher specimens were pressed and stored in 5\% formol for the identification. The samples were observed under a light microscope for anatomical examination and were identified according to the characteristics and identification keys in the taxonomic publications (Børgesen 1939; Lawson and John 1982; Teo and Wee 1983; Tseng 1984; Coppejans et al. 2001). The samples were kept at $50^{\circ} \mathrm{C}$ until experiments were processed and milled into powder before the extraction.

Dried seaweed sample powder $(200 \mathrm{mg})$ was extracted with $6.0 \mathrm{~mL} 80 \%$ methanol in an ultrasonic bath for $20 \mathrm{~min}$, vortexed for $30 \mathrm{~min}$, and then left to stand at room temperature for $48 \mathrm{~h}$. The extract was centrifuged at $1500 x \mathrm{x}$ for $10 \mathrm{~min}$ and filtered through Watmann No.1 filter paper. The stock solutions of extracts were adjusted with $80 \%$ methanol to final concentration of $4.0 \mathrm{mg}$ $\mathrm{mL}^{-1}$. Dilutions were made to obtain concentrations $2,1,0.5$ and $0.1 \mathrm{mg} \mathrm{mL}^{-1}$.

\section{DPPH Free Radical Scavenging Activity}

The DPPH (1,1-diphenyl-2-picrylhydrazyl) radical scavenging activity was determined according to the method of Zhang et al. (2007) with slight modifications. Briefly, $100 \mu \mathrm{L}$ of each extract at various dilutions were mixed with $100 \mu \mathrm{L}$ of 0.16 $\mathrm{mM}$ DPPH methanolic solution. This mixture was vortexed for $1 \mathrm{~min}$, kept for $30 \mathrm{~min}$ in dark and then, the absorbance was read at $517 \mathrm{~nm}$ in an automated microplate reader (Sunrise-Elisa Reader, Tecan, Swiss). The antioxidant capacity was calculated using the following equation:

$\%$ Inhibition $=\left(\mathrm{A}_{\text {cotrol }}-\left(\mathrm{A}_{\text {sample }}-\mathrm{A}_{\text {blank }}\right) / \mathrm{A}_{\text {cotrol }}\right) \times 100$

Where the $A_{\text {cotrol }}$ is the absorbance of the control (DPPH without sample), the $\mathrm{A}_{\text {sample }}$ is the absorbance of the test sample (the sample test and DPPH solution), and the $A_{\text {blank }}$ is the absorbance of the sample blank (Sample without the DPPH solution). The half-maximal inhibitory concentration $\left(\mathrm{IC}_{50}\right)$ was calculated by the linear regression analysis and expressed as mean of three determinations. Ascorbic acid was used as positive control.

\section{Determination of Total Phenolics and Flavonoid Content}

Total phenolic content (TPC) of algal extracts was determined by Folin-Ciocalteu reagent according to the method of Antolovich et al. (2002) with minor modifications. In Brief, $20 \mu \mathrm{L}$ of extracts were mixed with $100 \mu \mathrm{L}$ of 1:10 Folin-Ciocalteu reagent followed by the addition of $\mathrm{Na}_{2} \mathrm{CO}_{3}(80$ $\mu \mathrm{L}, 7.5 \%)$. The assay was carried out in microplate. After incubation at room temperature for $2 \mathrm{~h}$ in dark, the absorbance at $600 \mathrm{~nm}$ was recorded. Gallic acid was used as the standard 
reference. TPC was expressed as mg Gallic acid equivalents per gram of sample ( $\left.\mathrm{mg} \mathrm{GAE} \mathrm{g}^{-1}\right)$.

Flavonoid content (FC) of each extract was determined by the colorimetric method (Chang et al. 2002). Briefly, $20 \mu \mathrm{L}$ of each extract was separately mixed with $20 \mu \mathrm{L}$ of $10 \%$ aluminium chloride, $20 \mu \mathrm{L}$ of $1 \mathrm{M}$ potassium acetate and 180 $\mu \mathrm{L}$ of distilled water and left at room temperature for $30 \mathrm{~min}$. The absorbance of the reaction was recorded at $415 \mathrm{~nm}$. The calibration curve was prepared by Rutin methanolic solutions at concentrations of 12.5 to $100 \mu \mathrm{g} \mathrm{mL}^{-1}$. FC was expressed as mg Rutin equivalents per gram of the sample (mg RE $\mathrm{g}^{-1}$ ).

\section{Statistical analysis}

Data were expressed as means \pm standard errors of three replicate determinations. All the statistical analysis were carried out using SPSS 16.0 for Windows. To determine whether there were any differences among the means, one way analysis (ANOVA) and the Duncan's new multiple range test were applied to the result. $\mathrm{P}$ values $<0.05$ were regarded to be significant. The Pearson correlation analysis was performed between the variables.

\section{RESULTS AND DISCUSSION}

During the study, eight samples including four Chaetomorpha species were collected from the northern coasts of the Persian Gulf. The species, location and time of collection are listed in Table 1. Due to the presence of different bioactive components with antioxidative potential in the crude extracts of the samples, many different methods have been used to investigate various samples in recent years. In the current study, the DPPH radical scavenging method was used to evaluate the antioxidant capacity of the seaweed extracts, because the use of DPPH radical provided an easy, rapid and convenient method to evaluate the antioxidants and radical scavengers (Nickavar et al. 2007).

Table 1 - The Chaetomorpha species and their collection information.

\begin{tabular}{cllll}
\hline Sample number Scientific name & Location & Latitude, Longitude & Collection time \\
\hline S1 & C.linum(O.F.Muller)Kutzing & Dayyer & N2750016, E05156193 & October 2011 \\
S2 & C.aerea(Dillwyn)Kutzing & Nayband gulf & N2723722, E05239738 & December 2010 \\
S3 & C.aerea(Dillwyn)Kutzing & Nayband gulf & N2723722, E05239738 & May 2011 \\
S4 & C.aerea(Dillwyn)Kutzing & Nayband gulf & N2723722, E05239738 & March 2011 \\
S5 & C.aerea(Dillwyn)Kutzing & Dayyer & N2749964, E05156178 & October 2011 \\
S6 & C.brachygona Harvey & Halileh(Bushehr) & N2850309, E05052397 & May 2011 \\
S7 & C.crassa(C.Agardh)Kutzing & Rostami & N2834676, E05140625 & May 2011 \\
S8 & C.crassa(C.Agardh)Kutzing & Bandargah(Bushehr) & N2849347, E05054234 & May 2011 \\
\hline
\end{tabular}

All seaweed extracts showed antioxidant activity to various degrees (Table 2). Lower $\mathrm{IC}_{50}$ value indicates higher antioxidant activity. As shown in Table 2, C. linum (S1) exhibited relatively high antioxidant activity with low $\mathrm{IC}_{50}$ which was significantly different compared with those of $C$. aerea (S3-S5), C. brachygona and C. crassa (p <
0.05). The $\mathrm{IC}_{50}$ of ascorbic acid as a standard antioxidant was estimated as $0.037 \pm 0.018 \mathrm{mg}$ $\mathrm{mL}^{-1}$ in this work and was significantly different in comparison to the seaweed extracts $(\mathrm{p}<0.05)$. The scavenging effect of ascorbic acid ranged from $16.67 \pm 2.98 \%$ at concentration of $5 \mu \mathrm{g} \mathrm{mL}^{-1}$ to $90.34 \pm 0.35 \%$ at concentration of $100 \mu \mathrm{g} \mathrm{mL}^{-1}$.

Table 2 - $\mathrm{IC}_{50}, \mathrm{TPC}$ and FC of the seaweed extracts.

\begin{tabular}{|c|c|c|c|c|}
\hline Sample number & Species & $\mathrm{IC}_{50}\left(\mathrm{mg} \mathrm{mL}^{-1}\right)$ & TPC(mgGAEg $\left.{ }^{-1}\right)$ & FC (mg RE $\left.g^{-1}\right)$ \\
\hline $\mathrm{S} 1$ & C. linum & $1.484 \pm 0.168^{a}$ & $2.895 \pm 0.415^{a}$ & $18.177 \pm 2.238^{a}$ \\
\hline S2 & C.aerea & $2.087 \pm 0.071^{a b}$ & $2.934 \pm 0.188^{a}$ & $11.923 \pm 0.087^{b c}$ \\
\hline S3 & C.aerea & $2.798 \pm 0.082^{b c}$ & $2.270 \pm 0.325^{a b}$ & $14.931 \pm 0.126^{b}$ \\
\hline S4 & C.aerea & $3.840 \pm 0.288^{c}$ & $1.583 \pm 0.257^{b c}$ & $11.944 \pm 0.997^{b c}$ \\
\hline S5 & C.aerea & $3.645 \pm 0.071^{c}$ & $1.530 \pm 0.108^{b c}$ & $10.805 \pm 0.765^{c}$ \\
\hline S6 & C.brachygona & $5.881 \pm 0.107^{d}$ & $2.479 \pm 0.395^{a}$ & $10.751 \pm 0.219^{c}$ \\
\hline S7 & C.crassa & $6.601 \pm 0.493^{d}$ & $1.060 \pm 0.145^{c}$ & $10.906 \pm 1.180^{c}$ \\
\hline $\mathrm{S} 8$ & C.crassa & $8.061 \pm 0.790^{e}$ & $0.850 \pm 0.069^{c}$ & $6.743 \pm 0.111^{d}$ \\
\hline
\end{tabular}

Each value is expressed as the mean \pm SE $(n=3)$. Means with different letters are significantly different at $\mathrm{P}<0.05$. 
According to Table 2, the $\mathrm{IC}_{50}$ of two samples of C. aerea (S2, S4) from one area in different collection times showed significant differences as well a siginificant variation was seen for the samples of C.crassa (S7, S8) from different areas but at the same time of collection. These results suggested that collection time as well as location could influence the antioxidant properties of algal samples. The scavenging effect of the tested extracts at 1,2 and $4 \mathrm{mg} \mathrm{mL}^{-1}$ on the DPPH radical is shown in Figure 1. The extract of $C$. linum was the most potent scavenger at all the concentrations (43.43, 56.62 and $82.99 \%$, respectively) and was significantly different $(\mathrm{p}<0.05)$ when compared to the other seaweed extracts, except C.aerea (S2) at $4 \mathrm{mg} \mathrm{mL} \mathrm{m}^{-1}$. The scavenging activity of the C.aerea (S2) extract at $4 \mathrm{mg} \mathrm{mL}^{-1}$ was close to that of C. linum.

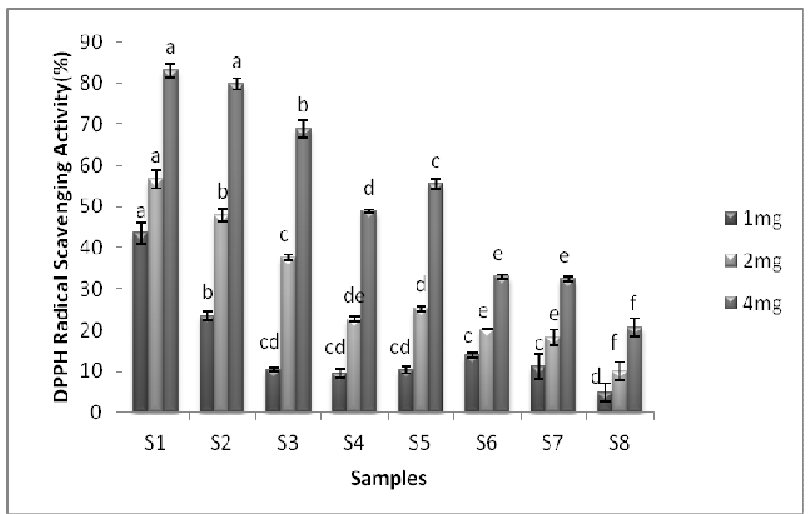

Each value is expressed as the mean $\pm \operatorname{SE}(n=3)$. Means with different letters (for each concentration level) are significantly different at $\mathrm{P}<$ 0.05 .

Figure 1 - DPPH radical scavenging activity of extracts at concentrations of 1,2 and $4 \mathrm{mg} \mathrm{mL}^{-1}$.

The DPPH radical scavenging values of all the extracts were dose dependent in the range of the tested concentrations. Many studies have been done to determine the antioxidant capacity of Chaetomorpha species and some researchers have stated high scavenging activity for these species. For instance, Sudha (2012) examined the antioxidant activity of the methanolic extract of $C$. linum based on the DPPH free radical-scavenging activity and reported a low $\mathrm{IC}_{50}$ (equivalent of 9.8 $\mu \mathrm{g} \mathrm{mL} \mathrm{L}^{-1}$ ascorbic acid) for this filamentous green algae. Heo et al. (2005) tested 35 marine algae, including 10 species of green algae for their antioxidant activity and reported the highest scavenging activity $(81.36 \%)$ for methanolic extract of $C$. linum at $2 \mathrm{mg} \mathrm{mL}^{-1}$ among the all the tested green algae. Aguilera and Dummermut (2002) carried out a survey of enzymatic defences in Arctic marine macroalgae and found a higher content of ascorbic acid in green algae in comparison to red and brown algae. They reported that the species from the eulittoral and upper sublittoral zones, including $C$. linum and $C$. melagonium had higher antioxidant enzyme activities in comparison to the species from the lower sublittoral zones, because of more efficient biochemical protection in algae exposed to higher stress conditions in the field.

Total phenolic content (TPC) and flavonoid content (FC) of the algal extracts are also presented in Table 2. The content of phenolic compounds of the extracts expressed as mg GAE $\mathrm{g}^{-1}$ varied from $2.895 \pm 0.415(\mathrm{~S} 1)$ and $2.934 \pm$ 0.188 (S2) to $0.85 \pm 0.069$ (S8). The phenolic content in the $C$. linum (S1), C. aerea (S2) and $C$. brachygona (S6) extracts were significantly different $(\mathrm{p}<0.05)$ compared with those of $C$. aerea (S4, S5) and C. crassa (S7, S8). In general, the higher total phenolic content resulted in higher antioxidant capacity, except for C. brachygona extract. According to Table 2, the phenolic content of two samples of $C$. aerea (S2, S4), which were collected from the same location were significantly different and was higher in C. aerea (S2), which was collected in December. The same result was observed with two samples (S2, S5) from different locations and different times of collection. The total phenolic contents of two species, including C. linum and C. aerea (S5) from the same area and the same collection time were significantly different. Similar result for two Halimeda species (of the same area) was reported by Yoshie et al. (2002). They stated that this difference in polyphenolic contents might be due to seasonal and local variations.

As shown in Table 2, the flavonoid content of algal extracts expressed as $\mathrm{mg} \mathrm{RE}^{-1}$ varied from $18.177 \pm 2.238$ (C. linum) to $6.743 \pm 0.111(C$. crassa (S8)). The flavonoid content of $C$. linum was significantly different from the other species. The flavonoid contents of two samples of $C$. crassa (S7, S8) from two different locations were significantly different, despite the fact that species were collected on the same day; however, the contents of their flavonoids were different.

The correlation between the phenolic and flavonoid content and $\mathrm{IC}_{50}$ are shown in Figures 2 and 3. The results showed that there were 
significant and negative correlations between the phenolic and flavonoid contents and $\mathrm{IC}_{50}$. The negative correlations showed that the antioxidant activity of Chaetomorpha species were in accordance with their amount of phenolic and flavonoid contents. The higher contents of phenolics and flavonoids resulted in higher antioxidant activity (with lower $\mathrm{IC}_{50}$ ). The Pearson's correlation coefficients between the variables are presented in Table 3. As illustrated in the table, there were positive and significant correlations between the DPPH radical scavenging and contents of the phenolics and flavonoids, and significant negative correlations between $\mathrm{IC}_{50}$ and the variables $(\mathrm{p}<0.01)$. In addition, the results revealed a strong positive correlation between the flavonoids and total phenolics $(r=0.552, \mathrm{p}<$ $0.01)$. Similar observations have been reported by Cho et al. (2010) and Chai and Wong (2012). The current research findings were in agreement with the results of Bouba et al. (2010), which reported a positive correlation between the total phenolics and flavonoids in the extracts of twenty Cameroonian spices. Flavonoids are polyphenolic compounds and the best-described property of almost every group of flavonoids is their capacity to act as antioxidants. Flavonoids are oxidized by the radicals, resulting in more stable, less-reactive radicals. In other words, flavonoids stabilize the reactive oxygen species by reacting with the reactive compound of the radical (Nijveldt et al. 2001). Several reports have shown a close relationship between the total phenolic content and high antioxidant activity, and many studies have demonstrated that phenolic compounds were one of the most effective antioxidant compounds in marine algae (Luo et al. 2010; Zakaria et al. 2011).

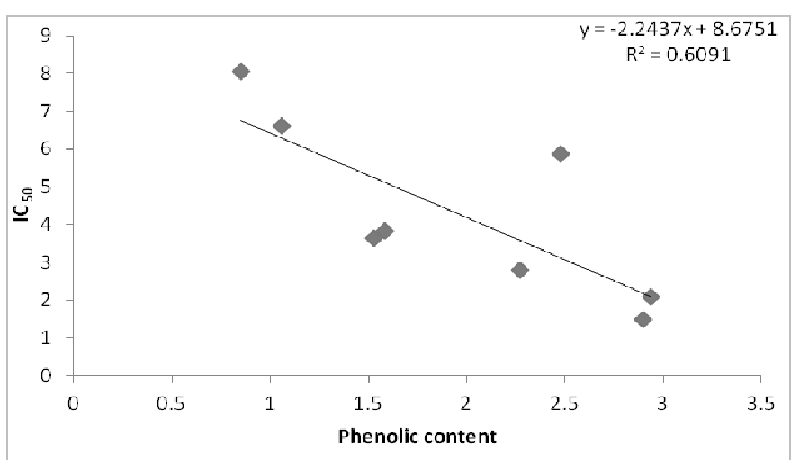

Correlation coefficient $r=-0.673$, coefficient of determination $\mathrm{R}^{2}=$ 0.6091. Correlation is significant at the 0.01 level (2-tailed).

Figure 2 - Linear correlation between phenolic content $\left(\mathrm{mg} \mathrm{GAE} \mathrm{g}^{-1}\right)$ and $\mathrm{IC}_{50}\left(\mu \mathrm{g} \mathrm{mL}^{-1}\right)$.

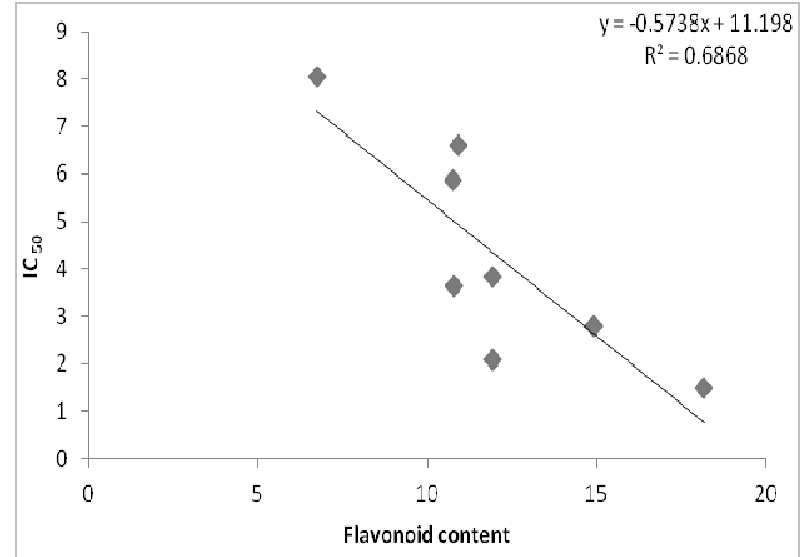

Correlation coefficient $r=-0.722$, coefficient of determination $R^{2}=$ 0.6868. Correlation is significant at the 0.01 level (2-tailed).

Figure 3 - Linear correlation between Flavonoid content (mg $\left.\mathrm{RE} \mathrm{g}^{-1}\right)$ and $\mathrm{IC}_{50}\left(\mu \mathrm{g} \mathrm{mL}^{-1}\right)$.

Table 3 - Pearson's correlation coefficients between the variables.

\begin{tabular}{llll}
\hline & $\begin{array}{l}\text { Phenolic } \\
\text { content }\end{array}$ & $\begin{array}{l}\text { Flavonoid } \\
\text { content }\end{array}$ & IC $_{\mathbf{5 0}}$ \\
\hline Flavonoid content & $0.552^{* *}$ & & \\
$\mathrm{IC}_{50}$ & $-0.673^{* *}$ & $-0.722^{* *}$ & \\
DPPH radical & $0.631^{* *}$ & $0.740^{* *}$ & $-0.625^{* *}$ \\
scavenging activity & & & \\
\hline$*$ Correlation is significant at the 0.01 level (2-tailed). &
\end{tabular}

Numerous studies have highlighted the antioxidant capacity of sulfated polysaccharides extracted from the seaweeds (Costa et al. 2010; Qi et al. 2010). The biological properties of sulfated arabinogalactans extracted from the green algae such Chaetomorpha have been investigated. For instance, Pierre et al. (2011) extracted and characterized an extracellular polysaccharide (a sulfated xyloarabinogalactan) from $C$. aerea with antibacterial activity against Staphylococcus aureus.

Previous studies have found marked changes in the chemical constituents with change of seasons and environmental conditions (Manivannan et al. 2009). The production of ROS especially occurs under the conditions during exposure to excessive light, or UV radiation as well as during desiccation, under nutrient deficiency, exposure to heavy metals, high, or low temperatures and temperature changes (Dummermuth et al. 2003). It has been observed that the production of ROS in marine algae is stimulated by various environmental stresses such as high light levels, heavy metals, high salt concentrations, UV 
radiation, etc. Algae generally have higher antioxidant activity due to higher contents of nonenzymatic antioxidant components such as ascorbic acid, reduced glutathione, phenols and flavonoids (Wu et al. 2010).

In the current study, the seaweeds were collected from different locations and different times. This variation in the phenolic and flavonoid contents could be due to the variation in physico-chemical parameters such as salinity amongst the selected stations. Besides, the seaweeds collected from the upper and middle intertidal zones were exposed to UV radiation for several hours a day. Prolonged seaweed exposure to solar UV radiation may result in producing the bioactive compounds such as phenolics and flavonoids and may be an explanation of possessing antioxidant activity.

\section{CONCLUSION}

The results clearly indicated that all the tested seaweeds possessed antioxidant activity. C. linum exhibited higher antioxidant activity in comparison to other seaweeds. The results also revealed that total phenolics and flavonoid content (as the main contributors of antioxidant activity in these Chaetomorpha species) and IC50, were influenced by the time of collection and location. However, to the best of our knowledge, this was the first report of investigation on the antioxidant properties of filamentous green algae in south of Iran. Since Chaetomorpha species are common algae species that inhabit the intertidal zone and easily collected, they can be used as natural antioxidant resources. Therefore, these species can be cultivated, or grown wild as food to be used for human beings, farm animals, or in the food supplement after being ensuring their safe nature.

\section{ACKNOWLEDGMENTS}

The authors appreciate Dr. M.E. Azemi, Department of Pharmacognosy, School of Pharmacy, Jundishapur University of Medical Sciences, Ahvaz, for laboratory facilities to carry out this study. The present work was also supported by the Natural Resources Research Center of Ahvaz. Authors also thank A. Kajkolahi for her help in seaweeds preparation and extraction.

\section{REFERENCES}

Aguilera J, Dummermuth A. Karsten U, Schriek R, Wiencke C. Enzymatic defences against photooxidative stress induced by ultraviolet radiation in Arctic marine macroalgae. Polar Biol. 2002; 25(6): 432-441.

Antolovich M, Prenzler PD, Patsalides E, Mc Donald S and Robards K. Methods for testing antioxidant activity. Analyst. 2002; 127(1): 183-198.

Apaydin-Yagci MA, Turna II. A new record for the algal flora of Turkey: Chaetomorpha crassa(C.Ag.) Kutz. (Cladophoraceae,Chlorophyceae). Turk J Bot. 2002; 26(3): 171-174.

Boonchum W, Peerapornpisal Y, Kanjanapothi D, Pekkoh J, Pumas C, Jamjai U, et al. Antioxidant activity of some seaweeds from the Gulf of Thailand. Int J Agric Biol. 2011; 13(1): 95-99.

Børgesen F. Marine algae from the Iranian Gulf. In: Danish Scientific Investigation in Iran, part 1, Copenhagen: Ejnar Munksgaard; 1939.

Bouba A, Njintang YN, Scher J, Mbofung CMF. Phenolic compounds and radical scavenging potential of twenty Cameroonian spices. Agric Biol J N Am. 2010; 1(3): 213-224.

Chai TT, Wong FC. Whole-plant profiling of total phenolic and flavonoid contents, antioxidant capacity and nitric oxide scavenging capacity of Turnera subulata. J Med Plants Res. 2012; 6(9): 1730-1735.

Chang C, Yang M, Wen H, Chern J. Estimation of total flavonoid content in propolis by two complementary colorimetric methods. J Food Drug Anal. 2002; 10(3): 178-182.

Cho M, Kang IJ, Won MH, Lee HS, You S. The antioxidant properties of ethanol extracts and their solvent-partitioned fractions from various green seaweeds. J Med Food. 2010; 13(5): 1232-1239.

Costa LS, Fidelis GP, Cordeiro SL, Oliveira RM, Sabry DA, Câmara RBG, et al. Biological activities of sulfated polysaccharides from tropical seaweeds. Biomed Pharmacother. 2010; 64(1): 21-28.

Coppejans E, Leliaert F, Dargent O, De Clerck O. Marine algae (Chlorophyta) from the north coast of Papua New Guinea. Cryptogamie Algol. 2001; 22(4): 1-69.

Cox S, Abu-Ghannam N and Gupta S. An assessment of the antioxidant and antimicrobial activity of six edible Irish seaweeds. Int Food Res J. 2010; 17(1): 205-220.

Duan XJ, Zhang WW, Li XM, Wang BG. Evaluation of antioxidant property of extract and fractions obtained from a red alga, Polysiphonia urceolata. Food Chem. 2006; 95(1): 37-43.

Dummermuth AL, Karsten U, Fisch KM, Konig GM, Wiencke C. Responces of marine macroalgae to hydrogen-peroxide stress. J Exp Mar Biol Eco. 2003; 289(1): 103-121. 
Hazra B, Sarkar R, Biswas S, Mandal N. Comparative study of the antioxidant and reactive oxygen species scavenging properties in the extracts of the fruits of Terminalia chebula,Terminalia belerica and Emblica officinalis. BMC Complem Altern M. 2010; 10(5): 20-35.

Heo SJ, Cha SH, Lee KW, Cho SK, Jeon YJ, Antioxidant activities of Chlorophyta and Phaeophyta from Jeju Island. Algae. 2005; 20(3): 251-260.

Kelman D, Kromkorski Posner E, McDermid KJ, Tabandera NK, Wright PR, Wright AD. Antioxidant activity of Hawaiian marine algae. Mar Drugs. 2012; 10(2):403-406.

Kulisic T, Radonic A, Katalinic V. Use of different methods for testing antioxidative of Oregano essential oil. Food Chem. 2004; 85(4):633-640.

Lawson GW, John DM. The Marine Algae and Coastal Environment of Tropical West Africa, Tropical West Africa. Vaduz: J Cramer; 1982.

Lee HH, Lin CT, Yang LL. Neuroprotection and free radical scavenging effects of Osmanthus fragrans. $J$ Biomed Sci. 2007; 14(6): 819-827.

Leliaraert F, D'hondt S, Tyberghein L, Verbruggen H, De Clerck O. Atypical development of Chaetomorpha antennina in culture (Cladophorales,Chlorophyta). Physiol Res. 2011; 59(2): 91-97.

Luo HY, Wang B, Yu CG, Qu YL, Su CL. Evaluation of antioxidant activities of five selected brown seaweeds from China. J Med Plants Res. 2010; 4(18): 2557-2565.

Manivannan K, Thirumaran G, Karthikai Devi G, Anantharaman P, Balasubramanian T. Proximate composition of different group of seaweeds from Vedalai coastal waters (Gulf of Mannar): Southest coast of India. Middle-East J Sci Res. 2009; 4(2): 7277.

Nickavar B, Kamalinejad M, Izadpanah H. In vitro free radical scavenging activity of five Salvia species. Pak J Pharm Sci. 2007; 20(4): 291-294.

Nijveldt RJ, van Nood E, van Hoorn DEC, Boelens PG,van Norren K, van Leeuwen PAM. Flavonoids: a review of probable mechanisms of action and potential applications. Am J Clin Nutr. 2001; 74(4): 418-425.
Novaczek I. A Guide to the Common Edible and Medicinal Sea Plants of the Pacific Islands. The University of the South Pacific; 2001.

Pierre G, Sopena V, Juin C, Mastouri A, Graber M, Maugard T. Antibacterial activity of sulfated galactan extracted from the marine alga Chaetomorpha aerea against Staphylococcus aureus. Biotechnol Bioprocess Eng. 2011; 16(5); 937-945.

Qi H, Liu X, Ma J, Zhang Q, Li Z. In vitro antioxidant activity of acetylated derivatives of polysaccharide extracted from Ulva pertusa( Chlorophyta). J Med Plants Res. 2010; 4(23): 2445-2451.

Sudha S. Antioxidant and antibacterial properties of methanolic extract of green seaweed Chaetomorpha linum from gulf of Mannar: Southest coast of India. Jundishapur J Microbiol. 2012; 5(2):411-415.

Teo LW, Wee YC. Seaweeds of Singapore. 2nd ed. Singapore: Singapore University Press, National University of Singapore; 1983.

Tseng C K. Common Seaweeds of China. Beijing: Science Press; Amsterdam/Berkeley: Kugler Publications; 1984.

Wu SC, Wang FJ, Pan CL. The comparison of antioxidative properties of seaweed oligosaccharides fermented by two lactic acid bacteria. J Mar Sci Tech. 2010; 18(4): 537-545.

Yoshie Y, Wang W, Hsieh Y, Suzuki T. Compositional difference of phenolic compounds between two seaweeds, Halimeda spp. J Tokyo Univ Fish. 2002; 88(1): 21-24.

Zakaria NA, Ibrahim D, Sulaiman SF, Supardy A. Assessment of antioxidant activity, total phenolic content and in vitro toxicity of Malaysian red seaweed, Acanthophora spicifera. J Chem Pharm Res. 2011; 3(3): 182-191.

Zhang WW, Duan XJ, Huang HL, Zhang Y, Wang B G. Evaluation of 28 marine algae from the Qingdao coast for antioxidative capacity and determination of antioxidant efficiency and total phenolic content of fractions and subfractions derived from Symphyocladia latiuscula (Rhodomelaceae). J Appl Phycol. 2007; 19(2): 97-108. 